\title{
Arsenic compounds induce apoptosis through caspase pathway activation in MA-10 Leydig tumor cells
}

\author{
YI-FEN MU $^{1 *}$, YING-HUI CHEN $^{2 *}$, MING-MIN CHANG ${ }^{1}$, YUNG-CHIA CHEN $^{3}$ and BU-MIIN HUANG ${ }^{1,4}$ \\ ${ }^{1}$ Department of Cell Biology and Anatomy, College of Medicine, National Cheng Kung University, Tainan 70101; \\ ${ }^{2}$ Department of Anesthesia, Chi-Mei Medical Center, Liouying, Tainan $73657 ;{ }^{3}$ Department of Anatomy, \\ School of Medicine, Kaohsiung Medical University, Kaohsiung 80708; ${ }^{4}$ Department of Medical Research, \\ China Medical University Hospital, China Medical University, Taichung 40402, Taiwan, R.O.C.
}

Received September 19, 2018; Accepted April 18, 2019

DOI: $10.3892 / 01.2019 .10386$

\begin{abstract}
The incidence of testicular cancer is increasing worldwide. Leydig cell tumors represent one type of sex cord-stromal testis malignancy, which tend to respond unfavorably to chemotherapies. Identifying more efficient treatment strategies is therefore crucial for patients. The present study aimed to investigate the apoptotic effects of arsenic compounds and their underlying mechanisms. The results indicated that sodium arsenite and dimethylarsenic acid induced apoptosis of the murine Leydig tumor cell line, MA-10. These apoptotic effects were characterized morphologically by membrane blebbing and cell detachment assays, biochemically using a cell viability assay, and cytologically by flow cytometry analysis. Western blotting demonstrated that caspases-3, -8 and -9 , and poly(ADP-ribose) polymerase protein levels were increased compared with untreated MA-10 cells; however, the caspase inhibitor, Z-VAD-fmk, reversed these effects. In conclusion, the present study has shown that sodium arsenite and dimethylarsenic acid may activate the intrinsic and extrinsic caspase pathways, and induce MA-10 cell apoptosis. These results suggest that sodium arsenite and dimethylarsenic acid may represent novel approaches to treat clinically unmanageable forms of testicular cancer.
\end{abstract}

Correspondence to: Professor Bu-Miin Huang, Department of Cell Biology and Anatomy, College of Medicine, National Cheng Kung University, 1 University Road, Tainan 70101, Taiwan, R.O.C.

E-mail: bumiin@mail.ncku.edu.tw

Professor Yung-Chia Chen, Department of Anatomy, School of Medicine, Kaohsiung Medical University, 100 Shih-Chuan 1st Road, Kaohsiung 80708, Taiwan, R.O.C.

E-mail: yungchia@kmu.edu.tw

${ }^{*}$ Contributed equally

Key words: sodium arsenite, dimethylarsenic acid, Leydig cells, testicular cancer, apoptosis, caspase

\section{Introduction}

Arsenic is a widespread environmental metalloid present in nature as oxide and sulfide compounds. Inorganic arsenic compounds comprise numerous valence states, including arsenic trioxide $\left(\mathrm{As}_{2} \mathrm{O}_{3}\right)$, realgar $\left(\mathrm{As}_{2} \mathrm{~S}_{2}\right)$, As (III), and As (V). As (III) has been used treat tumors with a positive effect; although, due to its' higher solubility and bioavailability, it may be more toxic than As (V) (1). Organoarsenic compounds comprise liver detoxification metabolites, including dimethylarsenic acid [DMA; $\left.\left(\mathrm{CH}_{3}\right)_{2} \mathrm{AsO}_{2} \mathrm{H}\right]$ and 4-[N-(S-glutathionylacetyl) amino] phenylarsonic acid (GSAO) (2). It has been demonstrated that $\mathrm{As}_{2} \mathrm{O}_{3}$ treats acute promyelocytic leukemia due to its antitumorigenic properties $(3,4)$. Furthermore, in vitro studies have revealed that $\mathrm{As}_{2} \mathrm{O}_{3}$ induces apoptosis in various types of cell line, including the DU145 and PC-3 (prostate cancer) (5), MDAH 2774 (ovarian cancer) (5) and TM4 (sertoli tumor) cell lines (6), and $\mathrm{CD} 133^{+} / \mathrm{CD} 13^{+}$liver cancer stem cells (7). In addition, GSAO, an organoarsenic compound, has been reported to inhibit proliferation in endothelial and tumor cells, such as fibrosarcoma cells, lung cancer, pancreatic cancer and prostate cancer cells in vitro, and reduce angiogenesis and tumor growth in a xenograft mouse model $(8,9)$. Furthermore, DMA exerts an antiproliferative and cytotoxic effect on human leukemia and multiple myeloma cells (10). Inorganic and organic arsenic compounds therefore represent novel potential therapeutic agents against solid tumors and various types of malignancy (3-10).

Previous studies have reported that tumor formation arises from an imbalance between cell proliferation and apoptosis. Subsequently, apoptosis induction is a potential target for cancer therapies $(11,12)$. Apoptosis is induced by various types of caspase, which are aspartatespecific cysteine proteases, during the extrinsic and intrinsic apoptosis pathways that involve death receptors and mitochondria, respectively. The extrinsic pathway is initiated from death receptors, e.g., tumor necrosis factor (TNF) receptor and Fas, which bind with their associated ligands, i.e., TNF and Fasligand (FasL), prior to subsequent caspase- 8 activation (13). The intrinsic pathway is caused by mitochondrial dysfunction, which leads to cytochrome $c$ release in the cytosol and subsequent formation of the apoptosome when combined with cleaved 
caspase-9 (14). These two caspase cascades eventually trigger caspase-3 activation and subsequent cellular morphological alterations, including membrane blebbing, phosphatidylserine externalization, cell detachment and chromosomal DNA fragmentation (15). In addition, proteins from the B-cell lymphoma-2 (Bcl-2) family are key regulators of the apoptotic response. They serve different physiological roles in mitochondrial integrity, including multidomain antiapoptotic (e.g. Bcl-2 and Bcl-extra-large), multidomain proapoptotic (e.g. Bcl-2 associated $\mathrm{X}$, apoptosis regulator and $\mathrm{Bcl}-2$ antagonist/killer), and $\mathrm{Bcl}-2$ homology region 3 (BH3)-only proapoptotic (e.g. BH3 interacting domain death agonist and Bcl-2 modifying factor) roles (16). These proteins can positively and negatively regulate mitochondrial permeability and apoptotic protein efflux (17-19). A previous study demonstrated that $\mathrm{As}_{2} \mathrm{O}_{3}$ upregulates $\mathrm{BH} 3$-only proapoptotic, and downregulates antiapoptotic, protein levels in myeloma (20). In addition, the extrinsic apoptotic pathway, which involves Fas/FasL, also participates in arsenic-induced keratinocyte apoptosis (21). The mechanisms underlying arsenic-induced apoptosis in various types of tumor cell are therefore complex, and have yet to be fully elucidated.

Leydig cell tumors are one type of sex cord-stromal malignancy observed in testicular cancer, accounting for 1-3\% of all testicular neoplasms and 4-9\% of tumors of the testis in prepubertal boys. Epidemiological studies have reported that the incidence of testicular cancer has been increasing worldwide over the past 30 years (22). Clinically, the major therapeutic strategy for Leydig cell tumor is radical orchiectomy. Testis sparing surgery is preferred in order to maintain fertility. In addition, $\sim 10 \%$ of Leydig cell tumors respond unfavorably to chemotherapy and irradiation (23). The present study aimed therefore to explore alternative therapeutic strategies to treat Leydig cell tumors. Particularly, this study aimed to determine the mechanisms underlying the arsenicinduced cell apoptosis in Leydig cell tumors. To do so, the effect of arsenic compounds, including sodium arsenite and DMA, which are the most representative inorganic and organic arsenite compounds, respectively (8), were investigated in MA-10 mouse Leydig tumor cells, which may aid the development of potentially more effective chemotherapy strategies.

\section{Materials and methods}

Chemicals. Sodium arsenite was purchased from Fluka (St. Gallen, Switzerland). DMA, RNase A, Waymouth's MB 752/1 medium, propidium iodide (PI), Folin \& Ciocalteu's phenol reagent, EDTA, EGTA, 30\% acrylamide/Bisacrylamide solution, MTT and anti- $\beta$-actin monoclonal antibody were purchased from Sigma-Aldrich; Merck KGaA (Darmstadt, Germany). Fetal bovine serum (FBS) and trypsin-EDTA were purchased from Gibco; Thermo FisherScientific,Inc. (Waltham, MA, USA). Gentamycin sulfate was purchased from AG Scientific Inc. (San Diego, CA, USA). Sodium chloride $(\mathrm{NaCl})$, HEPES, potassium chloride and Tris base were purchased from J.T. Baker (Phillipsburg, NJ, USA). Disodium hydrogen phosphate, potassium dihydrogen phosphate, and tissue culture grade sodium bicarbonate were purchased from Riedel-de Haën (Seelze, Germany). Hydrochloric acid, sodium dodecyl sulfate (SDS), Tween-20 and dimethyl sulfoxide (DMSO) were purchased from Merck KGaA. Sucrose was purchased from Panreac (Barcelona, Spain). The general caspase inhibitor Z-VAD-fmk was purchased from R\&D Systems, Inc. (Minneapolis, MN, USA). Goat horseradish peroxidase (HRP)-conjugated anti-rabbit immunoglobulin (Ig)G (cat. no. NEF812001EA; 1:2,000) and HRP-conjugated antimouse IgG secondary antibodies (cat. no. NEF822001EA; 1:2,000) were purchased from PerkinElmer, Inc. (Waltham, MA, USA). The Annexin V-fluorescein isothiocyanate (FITC) apoptosis detection kit was purchased from Strong Biotech (Taipei, Taiwan). Polyclonal antibodies against cleaved caspases-3 (cat. no. 9661; 1:2,000), cleaved caspase-8 (cat. no. 9429; $1: 2,000)$ and cleaved caspase-9 (cat. no. 9509; 1:2,000) and poly(ADP-ribose) polymerase (PARP; cat. no. 9542; 1:2,000) were purchased from Cell Signaling Technology, Inc. (Danvers, MA, USA). The enhanced chemiluminescence (ECL) detection kit was purchased from EMD Millipore (Billerica, MA, USA).

Cell culture and treatments. The MA-10 cell line was kindly donated by Dr Mario Ascoli (University of Iowa, Iowa City, IA, USA), and maintained using standard techniques as previously described $(24,25)$. Briefly, cells were cultured in Waymouth's MB 752/1 medium supplemented with $10 \%$ FBS and placed at $37^{\circ} \mathrm{C}$ in a humidified incubator containing $5 \% \mathrm{CO}_{2}$. A total of $6 \times 10^{6}$ MA-10 cells were plated in a $60-\mathrm{mm}$ dish. After $24 \mathrm{~h}$, MA-10 cells were treated with $0.01-100 \mu \mathrm{M}$ sodium arsenite, $0.1 \mu \mathrm{M}-10 \mathrm{mM}$ dimethylarsenic acid or PBS (Control) in the medium containing $1 \%$ FBS for 3, 6, 12 and $24 \mathrm{~h}$.

Morphological observation. The morphology of arsenic compound-treated MA-10 cells and control cells at 3, 6, 12 and $24 \mathrm{~h}$ after treatment was examined using an Olympus CK40 light microscope (Olympus Corporation, Tokyo, Japan) and images were captured using an Olympus DP20 digital camera (Olympus Corporation; magnification, x200). Apoptosis was characterized by assessing plasma membrane blebbing and detached cells, as described previously (26).

Cell viability assay. Cell viability was assessed with MTT assay as described previously (27), following treatment with arsenic compounds. In brief, MA-10 cells were seeded in 96-well plates at a density of $8 \times 10^{3}$ cells per well and $50 \mu \mathrm{l}$ MTT $(0.5 \mathrm{mg} / \mathrm{ml})$ was added to each well after 24,48 and $72 \mathrm{~h}$ after treatment with arsenic compounds, and incubated at $37^{\circ} \mathrm{C}$ for $4 \mathrm{~h}$. The supernatant was discarded and the MTT-formazan crystals were dissolved with $50 \mu 10.5 \%$ DMSO in each well for $1 \mathrm{~h}$. The optical density (OD) values were read using a VersaMax ELISA microplate reader (Molecular Devices, LLC, Sunnyvale, CA, USA) at a wavelength of $570 \mathrm{~nm}$.

Cell cycle analysis. Cell cycle distribution was determined by flow cytometry following PI staining (28). After $18 \mathrm{~h}$ of serum starvation, MA-10 cells were treated with arsenic compounds for 3, 6, 12 and $24 \mathrm{~h}$, and then cells were detached using $1 \%$ trypsin and fixed with $70 \%$ ethanol for $2 \mathrm{~h}$ at $-20^{\circ} \mathrm{C}$. Fixed cells were simultaneously treated with RNase $(100 \mu \mathrm{g} / \mathrm{ml})$ and PI $(40 \mu \mathrm{g} / \mathrm{ml})$ for $30 \mathrm{~min}$ at room temperature and analyzed using flow cytometry on a FACScan ${ }^{\mathrm{TM}}$ (Becton-Dickinson and Company, Franklin Lakes, NJ, USA) with an excitation 
wavelength of $488 \mathrm{~nm}$ and a band pass filter $>600 \mathrm{~nm}$. Cells in the sub- $\mathrm{G}_{1}$ phase, also termed hypodiploid, contain less DNA, which is due to apoptosisassociated DNA fragmentation (29).

Annexin V/PI double staining assay. A total of 6x106 MA-10 cells were seeded in a $60-\mathrm{mm}$ dish and treated 1 day after seeding with 10 or $100 \mu \mathrm{M}$ sodium arsenite, 1 or $10 \mathrm{mM}$ dimethylarsenic acid or PBS in the medium containing 1\% FBS for $24 \mathrm{~h}$. Treated-MA-10 cells were collected using trypsin and centrifuged at $120 \mathrm{x} \mathrm{g}$ for $10 \mathrm{~min}$ at $4^{\circ} \mathrm{C}$, and then incubated with $100 \mu \mathrm{l}$ Annexin V-FITC staining solution (apoptosis detection kit; Strong Biotech Corporation, Taipei, Taiwan) for $15 \mathrm{~min}$ at room temperature according to the manufacturer's protocol. Samples were analyzed on a FACSCalibur flow cytometer (Becton-Dickinson and Company) with an excitation wavelength of $488 \mathrm{~nm}$ and band pass filters of 515 and $600 \mathrm{~nm}$ for FITC and PI detection, respectively. Data were represented using histogram plots gated into four quadrants containing negative (Annexin V/PI), PIpositive (Annexin $\mathrm{V} / \mathrm{PI}^{+}$), Annexin Vpositive (Annexin $\mathrm{V}^{+} / \mathrm{PI}$ ) and Annexin V/PIdoublepositive (Annexin $\mathrm{V}^{+} / \mathrm{PI}^{+}$) stained cells, which corresponded to viable, dead, early apoptotic and late apoptotic cells, respectively (30).

Protein extraction and western blotting. Treated cells were lysed with $100 \mu \mathrm{l}$ ice-cold lysis buffer for $30 \mathrm{~min}$ at room temperature, which contained $20 \mathrm{mM}$ Tris at $\mathrm{pH} 7.5,150 \mathrm{mM}$ $\mathrm{NaCl}, 1 \mathrm{mM}$ EDTA, 1 mM EGTA, 1\% Triton X-100, $2.5 \mathrm{mM}$ sodium pyrophosphate and $1 \mathrm{mM}$ sodium orthovanadate. Lysates were centrifuged at $12,000 \mathrm{x} \mathrm{g}$ for $12 \mathrm{~min}$ at $4^{\circ} \mathrm{C}$, and supernatants were collected and stored at $20^{\circ} \mathrm{C}$ until future analysis. Protein concentration was determined using the Lowry protein assay as described previously (31). Proteins $(30 \mu \mathrm{g})$ were separated by $12 \%$ SDS-PAGE and transferred onto polyvinylidene fluoride membranes. Membranes were blocked with $5 \%$ milk dissolved in TBST for $1 \mathrm{~h}$ at room temperature, and incubated with primary antibodies overnight at $4^{\circ} \mathrm{C}$. Membranes were then washed three times with TBST and incubated for $1 \mathrm{~h}$ with the appropriate HRP conjugated secondary antibodies. Bands were detected using ECL substrate and the UVP EC3 BioImaging system (UVP, LLC, Phoenix, AZ, USA) (32-34). Quantification of the western blotting data was performed using ImageJ version 1.50 software (National Institutes of Health, Bethesda, MD, USA).

Statistical analysis. All data were expressed as the means \pm standard error of the mean from three separate experiments. The statistical significance of the differences between the control and treatment groups at various time-points was determined using a two-way analysis of variance followed by the Least Significance Difference test. Statistical analysis was performed using GraphPad Prism version 6 (GraphPad Software, Inc., La Jolla, CA, USA). $\mathrm{P}<0.05$ was considered to indicate a statistically significant difference.

\section{Results}

Effects of arsenic compounds on MA-10 cell morphology and viability. To determine the cytotoxicity of arsenic compounds, MA-10 cells were treated with or without sodium arsenite
(0.01-100 $\mu \mathrm{M})$ and DMA $(0.1-10 \mathrm{mM})$ for 3, 6, 12 and $24 \mathrm{~h}$. At each time point, untreated MA-10 cells were firmly attached and exhibited the commonly anticipated polygonal-shaped morphology (Fig. 1A). Conversely, cells treated with $100 \mu \mathrm{M}$ sodium arsenite or $10 \mathrm{mM}$ DMA became gradually rounded and more detached over time (Fig. 1A and B, respectively). However, 12 and $24 \mathrm{~h}$ of treatment with $10 \mu \mathrm{M}$ sodium arsenite, and $24 \mathrm{~h}$ of treatment with $1 \mathrm{mM}$ DMA, induced plasma membrane blebbing and an enlarged and flattened appearance, which suggested that cell apoptosis was occurring (Fig. 1A and B). Sodium arsenite appeared to be more toxic than DMA to MA-10 cancer cells. However, low concentrations of sodium arsenite $(0.01,0.1$ and $1 \mu \mathrm{M})$ or DMA $(0.1$, $10 \mu \mathrm{M}$ and $10 \mathrm{mM}$ ) did not effect cell morphology.

The effects of arsenic compounds on MA10 cell morphology were further investigated with the MTT viability assay. MA10 cell viability significantly decreased to $88 \pm 2.9,84 \pm 7.4,74 \pm 3.8$ and $45 \pm 6.4 \%$ following 3, 6, 12 or and $24 \mathrm{~h}$ treatment with $10 \mu \mathrm{M}$ sodium arsenite, respectively, compared with the control group (Fig. 1C). MA-10 cell treatment with 10 mM DMA only significantly reduced cell viability to $99 \pm 6.9,79 \pm 6.6,84 \pm 0.8$ and $49 \pm 6.0 \%$ at the same time points (Fig. 1D). These results indicated that sodium arsenite and DMA both induced time and dosedependent cell toxicity, and that sodium arsenite was more potent (given the 1,000-fold difference in the concentration of the two compounds that elicited these effects).

Arsenic compounds induce MA10 cell apoptosis. To determine whether MA10 cells were undergoing apoptosis following treatment with arsenic compounds, cell DNA content was quantified using PI staining. A significant increase in the number of cells in the sub- $G_{1}$ phase, which is an apoptotic marker, was observed following 12 and $24 \mathrm{~h}$ treatment with $10 \mu \mathrm{M}$ sodium arsenite or $10 \mathrm{mM}$ DMA, respectively $(\mathrm{P}<0.05$; Fig. 2A and $\mathrm{C})$. In addition, the cell population in the $\mathrm{G}_{2} / \mathrm{M}$ phase was significantly increased following $24 \mathrm{~h}$ treatment with 10 and $100 \mu \mathrm{M}$ sodium arsenite, and $12 \mathrm{~h}$ treatment with $1 \mathrm{mM}$ DMA (12 and $24 \mathrm{~h}$ ), which indicated that both arsenic compounds caused $\mathrm{G}_{2} / \mathrm{M}$ cell cycle arrest of MA10 cells (Fig. 2B and D) $(\mathrm{P}<0.05)$. These results suggested that cell cycle regulation and redistribution may be involved in sodium arsenite- and DMA-induced MA-10 cell apoptosis.

Annexin V/PI double-staining was used to refine the apoptosis stages observed in MA-10 cells (Fig. 3A). A shift in alive (Annexin $\mathrm{V}^{-} / \mathrm{PI}^{-}$), dead (Annexin $\mathrm{V}^{-} / \mathrm{PI}^{+}$), early apoptotic (Annexin $\mathrm{V}^{+} / \mathrm{PI}^{-}$) and late apoptotic (Annexin $\mathrm{V}^{+} / \mathrm{PI}^{+}$) cell populations was observed following $24 \mathrm{~h}$ treatment with 10 and $100 \mu \mathrm{M}$ sodium arsenite, and with 1 and $10 \mathrm{mM}$ DMA (Fig. 3B and C, respectively). Notably, the differences in the Annexin $\mathrm{V}^{+}$-stained cells (early and late apoptotic status) were further analyzed following sodium arsenite (Fig. 3D) and DMA (Fig. 3E) treatments. The results demonstrated that both arsenic compounds significantly induced MA-10 cell apoptosis following $24 \mathrm{~h}$, as indicated by the increased ratio of Annexin $\mathrm{V}^{+}$cells $(\mathrm{P}<0.05)$. These results further suggested that sodium arsenite and DMA may be cytotoxic to Leydig cancer cells, particularly DMA.

Arsenic-induced MA-10 cell apoptosis is mediated by caspase cascade. The caspase cascades are essential regulators of the 
A
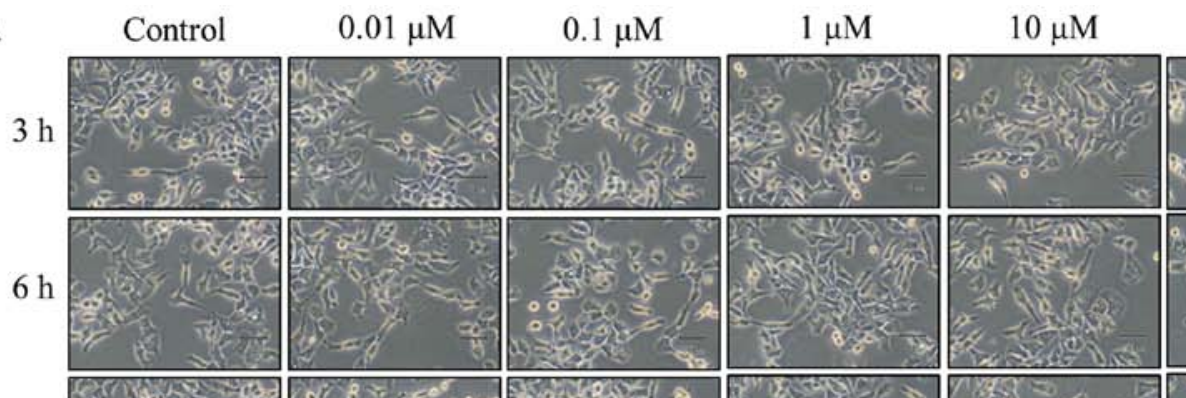

$100 \mu \mathrm{M}$

$12 \mathrm{~h}$
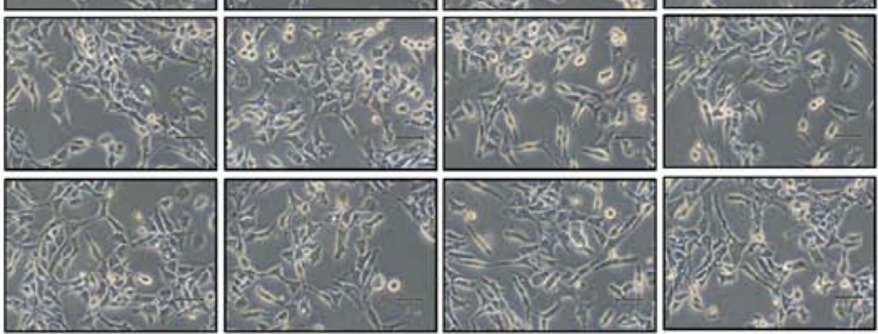

$24 \mathrm{~h}$

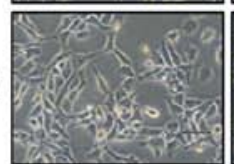

$0.1 \mu \mathrm{M}$

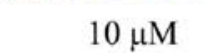

$1 \mathrm{mM}$
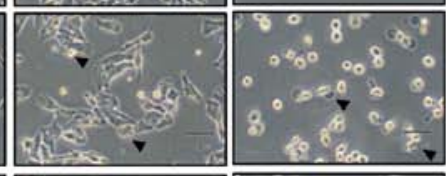

$\mathbf{B}$

Control
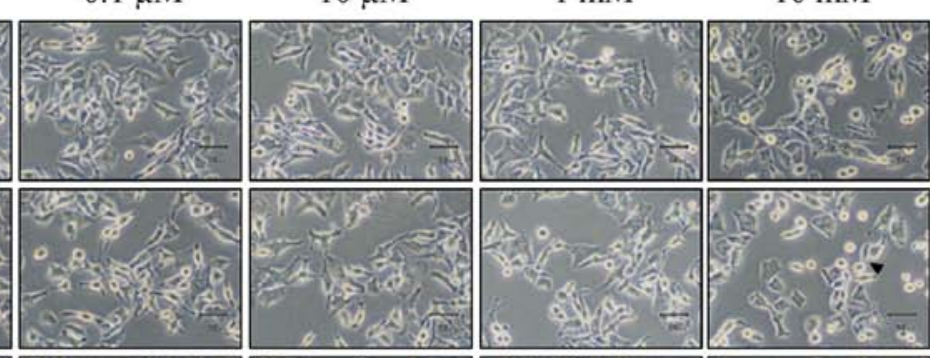

$12 \mathrm{~h}$

$6 \mathrm{~h}$

$3 \mathrm{~h}$
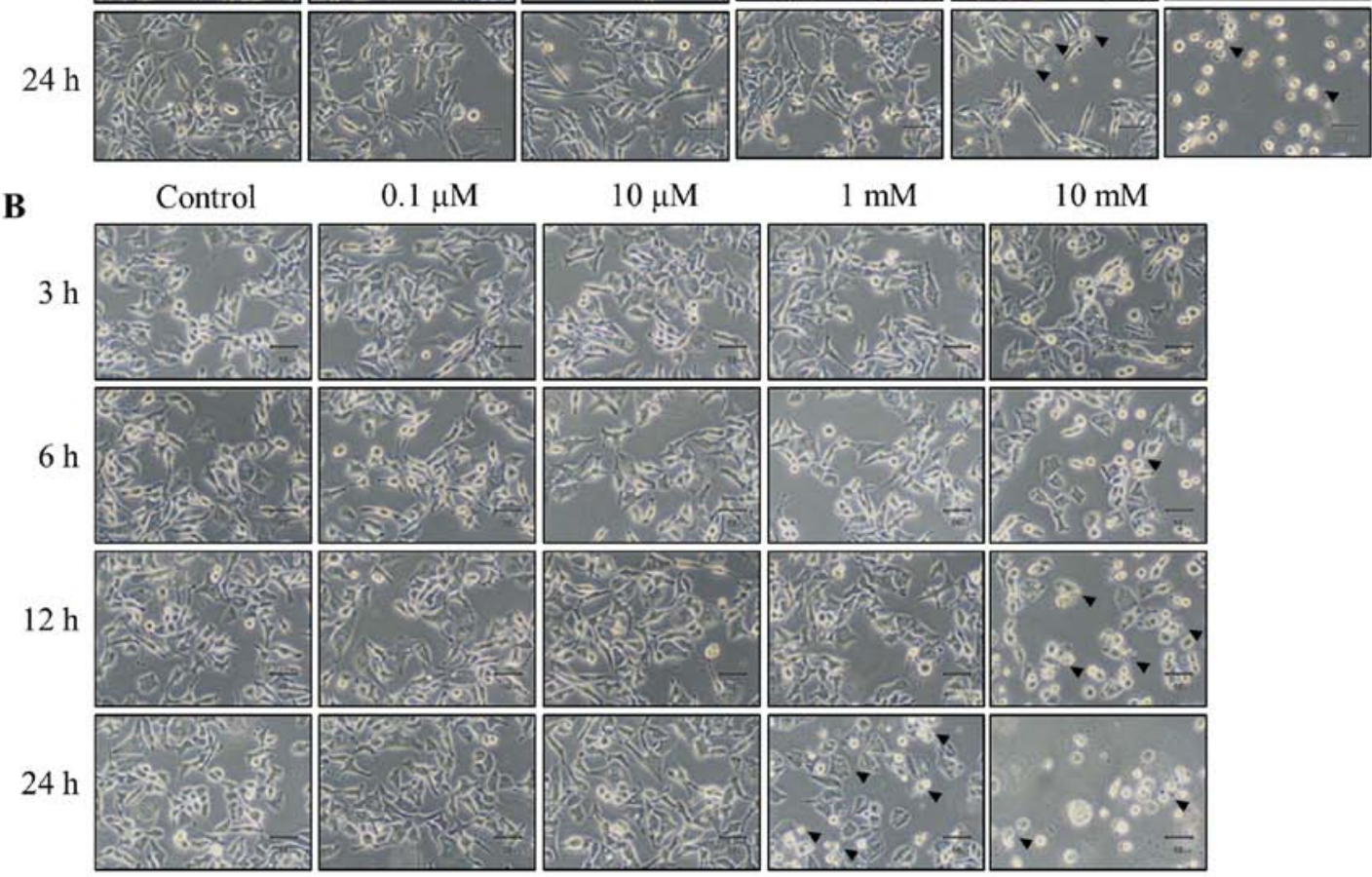

C

Sodium arsenite

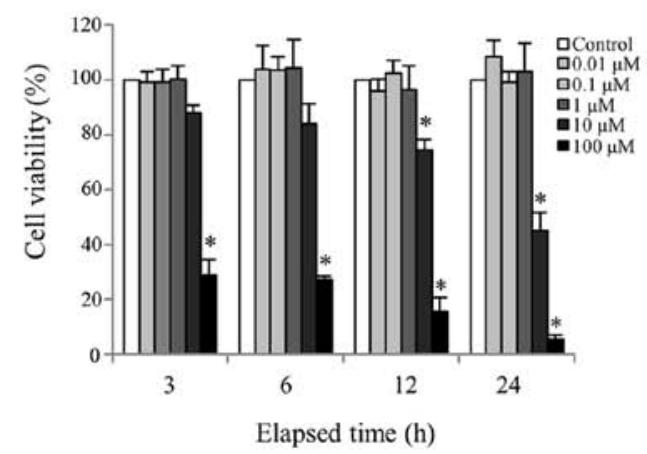

D
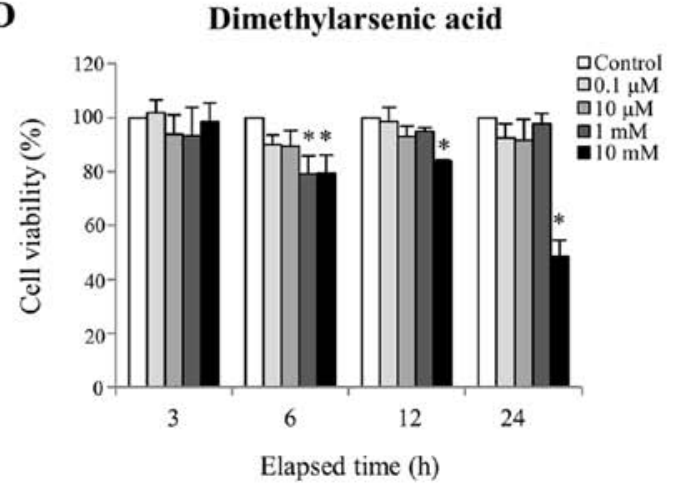

Figure 1. Effect of sodium arsenite and dimethylarsenic acid on cell morphology and viability. MA-10 cells were treated with sodium arsenite $(0.01-100 \mu \mathrm{M})$ and dimethylarsenic acid $(0.1 \mu \mathrm{M}-10 \mathrm{mM})$ for 3, 6, 12 and $24 \mathrm{~h}$. Morphological changes of MA-10 cells following (A) sodium arsenite and (B) dimethylarsenic acid treatments were observed and recorded under a light microscope. Magnification, x200; scale bar, $50 \mu \mathrm{m}$ ). Arrowheads represent the membrane blebbings. MA-10 cell viability following (C) sodium arsenite and (D) dimethylarsenic acid treatments were quantified by MTT viability assay. Results are expressed as the percentages of cell growth relative to control (100\%). Data in (C) and (D) represent the mean \pm standard error of the mean of three separate experiments. ${ }^{*} \mathrm{P}<0.05$.

apoptotic signaling transduction pathway (12). Activation of these cascades triggers PARP cleavage of its $85 \mathrm{kDa}$ C-terminal fragment. PARP cleavage, which is a common apoptosis marker, follows caspase-3 activation and cleavage (35). To investigate whether arsenic compounds affect the extrinsic and/or intrinsic apoptotic pathways, the protein levels of cleaved (activated) caspases- $3,-8$ and -9 were assessed by western blotting. The results demonstrated that 12 and $24 \mathrm{~h}$ treatment with $10 \mu \mathrm{M}$ sodium arsenite significantly increased cleaved caspase- 8 and -3 protein levels $(\mathrm{P}<0.05$; Fig. 4A, B and D). In addition, $24 \mathrm{~h}$ treatment with $10 \mu \mathrm{M}$ sodium arsenite significantly increased the cleaved caspase- 9 
A

\section{Sodium arsenite}

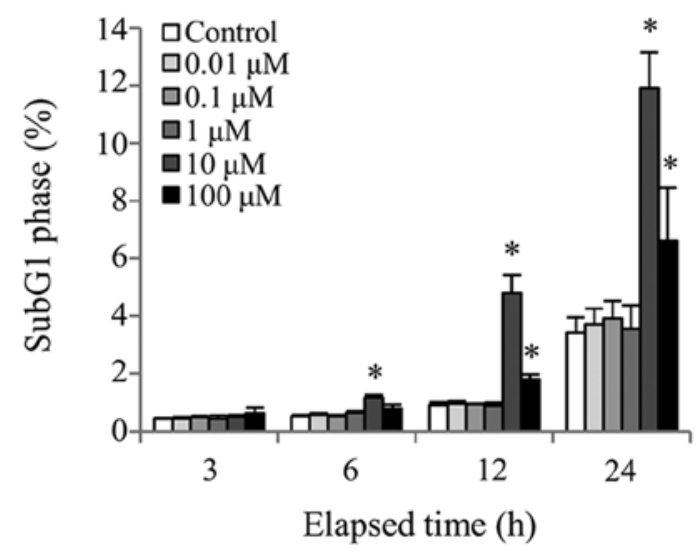

C

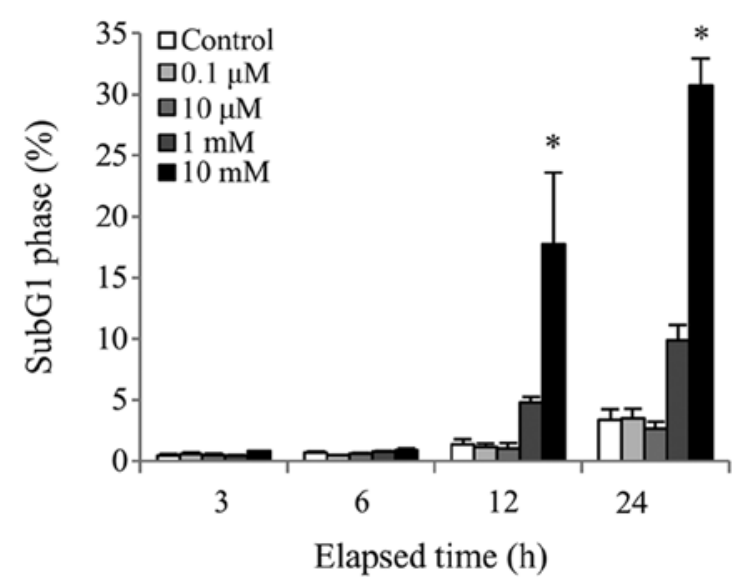

B

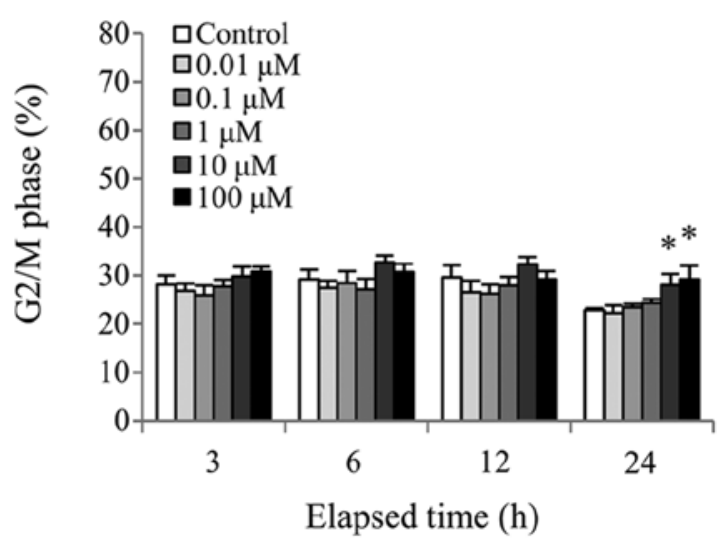

D

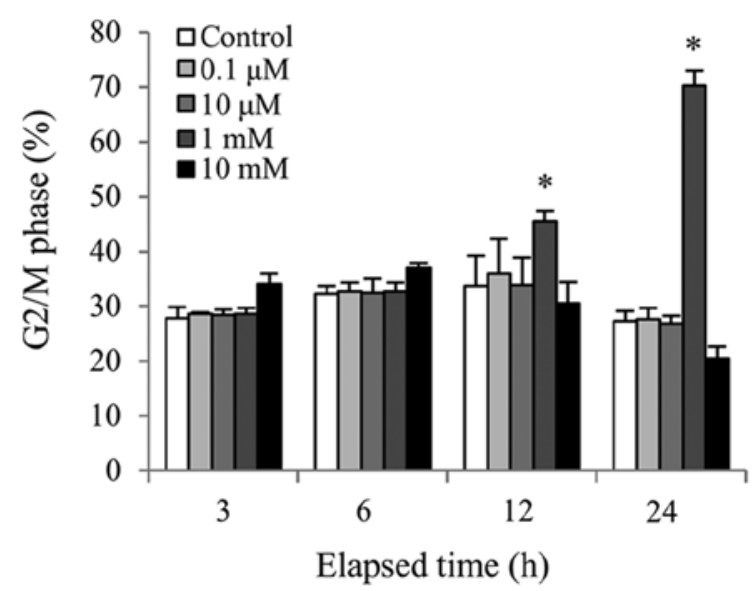

Figure 2. Effect of sodium arsenite and dimethylarsenic acid on cell cycle distribution. MA-10 cells were treated without or with sodium arsenite ( $0.01-100 \mu \mathrm{M})$ and dimethylarsenic acid $(0.1 \mu \mathrm{M}-10 \mathrm{mM})$ for 3, 6, 12 and $24 \mathrm{~h}$. Cells were stained with PI and analyzed for cell cycle distribution by flow cytometry. (A) and (B) represent sub- $\mathrm{G}_{1}$ and $\mathrm{G}_{2} / \mathrm{M}$ phases, respectively, following MA-10 cell treatment with sodium arsenite. (C) and (D) represent sub- $\mathrm{G}_{1}$ and $\mathrm{G}_{2} / \mathrm{M}$ phases, respectively, following MA-10 cell treatment with dimethylarsenic acid. Data represent the means \pm standard error of the mean of three separate experiments. ${ }^{*}<0.05$.

protein level (P<0.05; Fig. 4A and C). Furthermore, $12 \mathrm{~h}$ treatment with $10 \mu \mathrm{M}$ sodium arsenite significantly increased the cleaved PARP protein level (P<0.05; Fig. 4A and E). Treatment with $1 \mathrm{mM}$ DMA for $24 \mathrm{~h}$ significantly increased the cleaved caspase- 8 protein level $(\mathrm{P}<0.05$; Fig. $5 \mathrm{~A}$ and $\mathrm{B})$. In addition, $24 \mathrm{~h}$ treatment with 1 and $10 \mathrm{mM}$ DMA significantly elevated the cleaved caspase-9 protein level $(\mathrm{P}<0.05$; Fig. $5 \mathrm{~A}$ and $\mathrm{C})$. Furthermore, 12 and $24 \mathrm{~h}$ treatment with $10 \mathrm{mM}$ DMA significantly increased the cleaved caspase-3 protein level $(\mathrm{P}<0.05$; Fig. 5A and D). Finally, treatment with $10 \mathrm{mM}$ DMA for $12 \mathrm{~h}$ significantly increased the cleaved PARP protein level $(\mathrm{P}<0.05$; Fig. 5A and E). These results demonstrated that arsenic compounds are involved in the intrinsic and extrinsic apoptotic pathways in MA-10 cancer cells. In addition, these results further indicated that sodium arsenite was more potent than DMA in terms of activating caspase pathways in MA10 cells.

Caspase inhibitor reverses arsenic-induced MA-10 cell apoptosis. The membrane-permeable and irreversible pancaspase inhibitor Z-VAD-fmk was used to determine whether the cleavage of caspases $-3,-8$ and -9 could be abolished in arsenicinduced MA10 cell apoptosis. To do so, cells were pretreated with increasing concentrations of Z-VAD-fmk $(0.1,1,10$ and $100 \mu \mathrm{M})$ for $2 \mathrm{~h}$, followed by $10 \mu \mathrm{M}$ sodium arsenite or $1 \mathrm{mM}$ DMA treatment for $24 \mathrm{~h}$. The results from western blotting demonstrated that 10 and $100 \mu \mathrm{M}$ Z-VAD-fmk treatment significantly reduced caspase- 8 cleavage induced by $10 \mu \mathrm{M}$ sodium arsenite treatment $(\mathrm{P}<0.05$; Fig. 6A and B), compared with $10 \mu \mathrm{M}$ sodium arsenite treatment alone. In addition, treatment with 0.1-100 $\mu \mathrm{M} \mathrm{Z-VAD-fmk} \mathrm{signifi-}$ cantly reduced caspase- 9 protein cleavage $(\mathrm{P}<0.05$; Fig. $6 \mathrm{~A}$ and $\mathrm{C})$, and treatment with $100 \mu \mathrm{M} \mathrm{Z-VAD-fmk} \mathrm{significantly} \mathrm{decreased}$ caspase-3 protein activation $(\mathrm{P}<0.05$; Fig. $6 \mathrm{~A}$ and $\mathrm{D})$, compared with $10 \mu \mathrm{M}$ sodium arsenite treatment alone. Furthermore, 0.1, 10 , and $100 \mu \mathrm{M} \mathrm{Z}$-VAD-fmk treatment significantly reduced caspase- 8 activation $(\mathrm{P}<0.05$; Fig. 7A and $\mathrm{B}$ ) induced by $1 \mathrm{mM}$ DMA, compared with DMA alone. When used at a concentration range of 0.1-100 $\mu \mathrm{M}, \mathrm{Z}$-VAD-fmk significantly decreased caspase-9 cleavage $(\mathrm{P}<0.05$; Fig. $7 \mathrm{~A}$ and $\mathrm{C})$ induced by $1 \mathrm{mM}$ DMA, compared with DMA alone. In addition, treatment with $100 \mu \mathrm{M}$ Z-VAD-fmk significantly decreased caspase-3 cleavage $(\mathrm{P}<0.05$; Fig. 7A and $\mathrm{D})$ induced by $1 \mathrm{mM}$ DMA, compared with DMA alone. These results suggested that the caspase cascades may be crucial in arsenicinduced MA-10 cell apoptosis. 


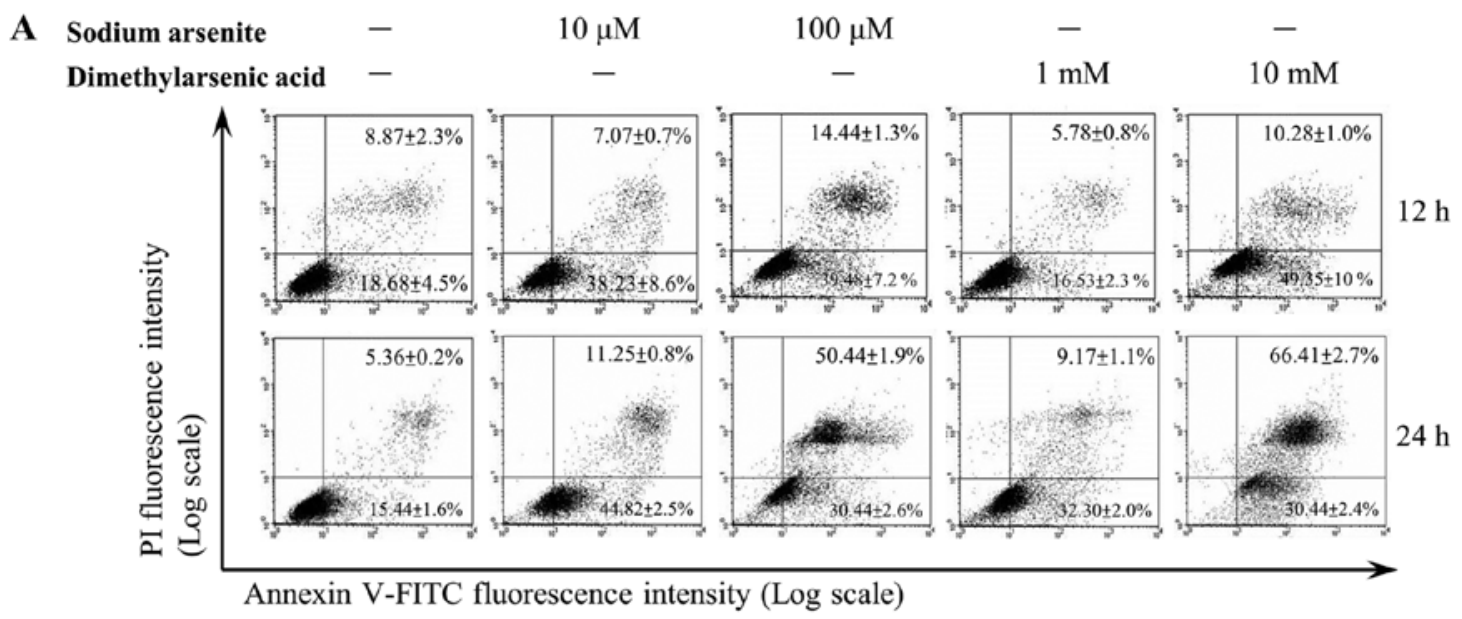

B

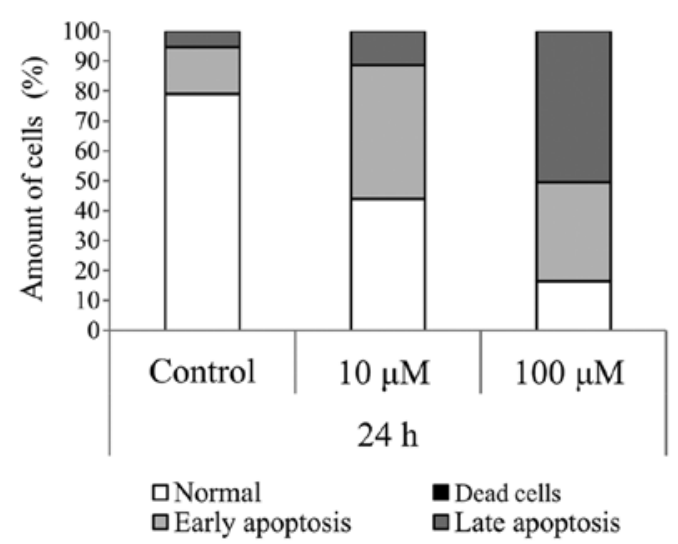

D

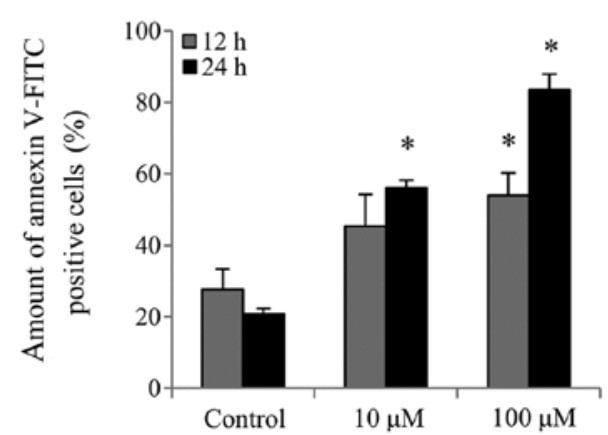

C

Dimethylarsenic acid

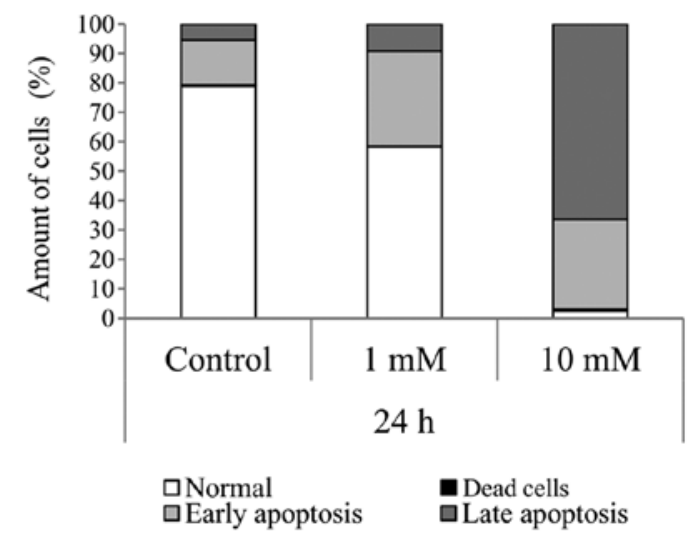

$\mathbf{E}$

Dimethylarsenic acid

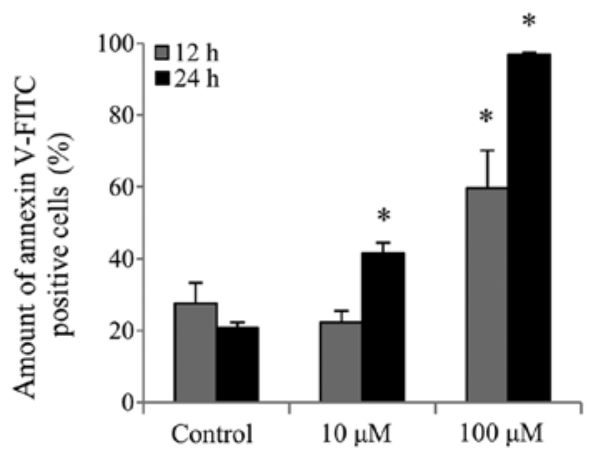

Figure 3. Effect of sodium arsenite and dimethylarsenic acid on cell apoptosis. MA-10 cells were treated without or with sodium arsenite (10 and $100 \mu \mathrm{M})$ and dimethylarsenic acid (1 and $10 \mathrm{mM}$ ) for 12 and $24 \mathrm{~h}$. (A) Apoptotic status of the arsenic-treated cells was determined by Annexin V/PI double staining. The proportion of negative (viable) cells, Annexin V-positive (early apoptotic) cells, PI-positive (dead) cells, and Annexin V and PI double-positive (late apoptotic) stained cells are shown following (B) sodium arsenite $(10$ and $100 \mu \mathrm{M})$ and (C) dimethylarsenic acid (1 and $10 \mathrm{mM})$ treatments. The differences in Annexin V-positive stained cells (early and late apoptotic) following (D) sodium arsenite and (E) dimethylarsenic acid treatments were further analyzed. Data represent the means \pm standard error of the mean of three separate experiments. ${ }^{*} \mathrm{P}<0.05$. FITC, fluorescein isothiocyanate; PI, propidium iodide.

\section{Discussion}

The results from the present study demonstrated that sodium arsenite and DMA induced MA-10 cell apoptosis through caspase pathway activation. The morphological analysis revealed that arsenictreated MA-10 cells became more closely associated with each other and exhibited membrane blebbing, a more rounded appearance and detachment, findings which were consistent with a previous study (15). It has been reported that arsenite blocks the guanosine-5'-triphosphate binding site of tubulin, which leads to microtubule polymerization disruption during mitosis (36). This may explain how arsenic compounds could target the cytoskeleton and cause an enlarged and flattened plasma membrane appearance, which was observed in MA-10 cells from the present study. In addition, the toxicity of arsenic compounds varies, according to the cellular function under consideration. For example, 
A

3

6

12

24

(h)

Sodium arsenite $(\mu \mathrm{M}) \overline{\mathrm{C} 0.010 .1110100} \overline{\mathrm{C} 0.010 .1110100} \overline{\mathrm{C} 0.010 .1110100} \overline{\mathrm{C} 0.010 .1110100}$

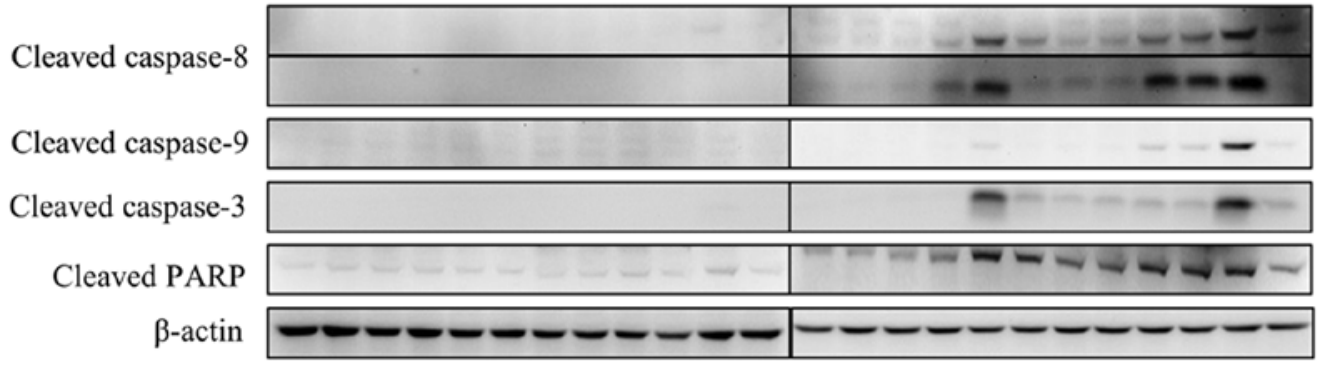

B

Sodium arsenite

C

Sodium arsenite

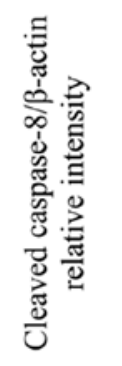

D
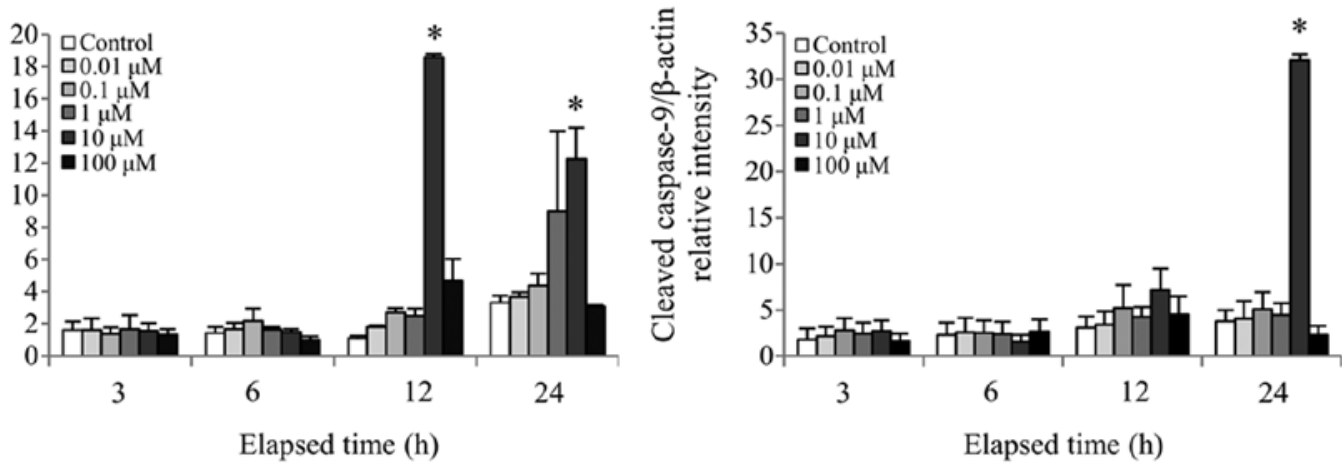

6

12

24

Elapsed time (h)

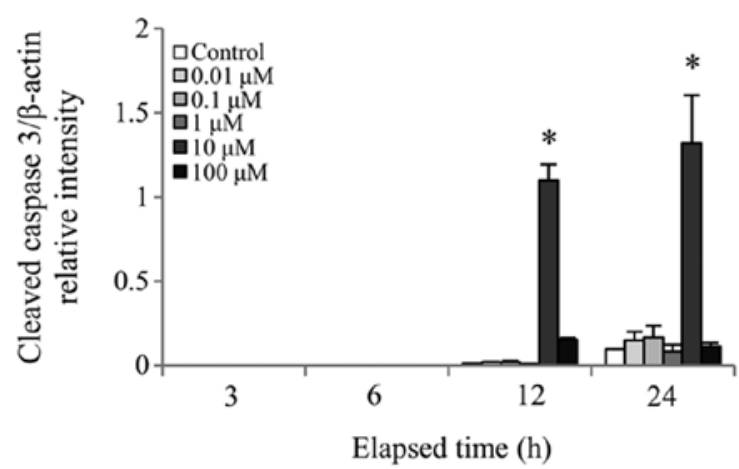

E

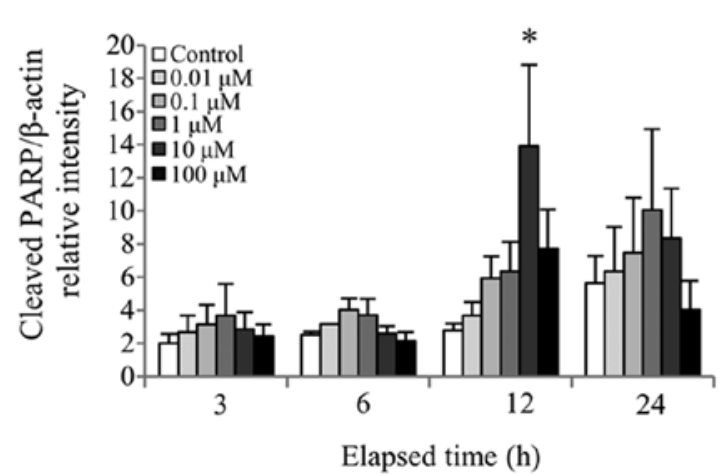

Figure 4. Effect of sodium arsenite on cleaved caspase-8, -9 and -3 and PARP protein expression in MA-10 cells. MA-10 cells were treated without or with sodium arsenite $(0.01-100 \mu \mathrm{M})$ for 3, 6, 12 and $24 \mathrm{~h}$. Cleaved caspase-8, -9 and -3 , and PARP protein expressions were detected by western blotting. (A) Data is representative of one experiment that was further repeated three times. The integrated optical densities of (B) cleaved caspase-8, (C) -9 and (D) -3 and (E) PARP protein expressions were analyzed after normalization to $\beta$-actin (43 kDa). Data in $\mathrm{B}, \mathrm{C}, \mathrm{D}$ and $\mathrm{E}$ represent the means \pm standard error of the mean of three separate experiments. ${ }^{*} \mathrm{P}<0.05$. PARP, poly(ADP-ribose) polymerase.

$\mathrm{AsO}_{2}$ - can alter the activity of cysteine-rich enzymes by interacting with sulfhydryl groups (37). However, methylated arsenics are metabolites of liver detoxification, which reduces acute arsenic toxicity (38). In the present study, cell viability was significantly decreased to $45 \%$ following $12 \mathrm{~h}$ treatment with $10 \mu \mathrm{M}$ sodium arsenite, and to $48 \%$ following $12 \mathrm{~h}$ treatment with $10 \mathrm{mM}$ DMA. These results demonstrated that sodium arsenite was 1,000-fold more potent than DMA in inducing MA-10 cell toxicity. These findings were comparable with those of other studies, where inorganic arsenite compounds were more toxic than inorganic arsenite compounds (36-38).

Cell cycle regulation is crucial in mammalian cells, and cell cycle checkpoints, including $\mathrm{G}_{1}$ and $\mathrm{G}_{2} / \mathrm{M}$, are key regulators that ensure appropriate DNA replication and division (39).
The $\mathrm{G}_{2} / \mathrm{M}$ checkpoint represents the acute response to DNA damage. Subsequently, abnormal $\mathrm{G}_{2} / \mathrm{M}$ arrest can trigger cell apoptosis (40). It has been reported that arsenite is involved in cell cycle disruption in myelomonocytic leukemia cells (41). In the present study, the cell number in the $G_{2} / M$ phase was significantly increased $24 \mathrm{~h}$ following treatment with arsenic compounds. A previous study indicated that arsenic trioxide can induce $\mathrm{G}_{2} / \mathrm{M}$ arrest through p53 phosphorylation and increased p21 expression in TM4 Sertoli cells (6). Arsenic-induced MA-10 cell apoptosis may therefore be associated with abnormal cell cycle distribution, and it would be interesting to further investigate the mechanism of cell cycle redistribution induced by arsenic compounds in MA-10 cells.

Previous studies have reported that arsenic trioxide induces apoptosis through caspase- 9 activation in cultured 
A

Dimethylarsenic acid $(\mu \mathrm{M})$

Cleaved caspase- 8

Cleaved caspase-9

Cleaved caspase-3

Cleaved PARP

$\beta$-actin
3

$\overline{\mathrm{C} 0.1 \quad 10 \quad 10^{3} 10^{4}} \overline{\mathrm{C} 0.1 \quad 1010^{3} \quad 10^{4}}$
12

$\begin{array}{llllllll}\text { C } 0.1 \quad 10 & 10^{3} & 10^{4} & \text { C } 0.1 \quad 10 & 10^{3} & 10^{4}\end{array}$

(h)
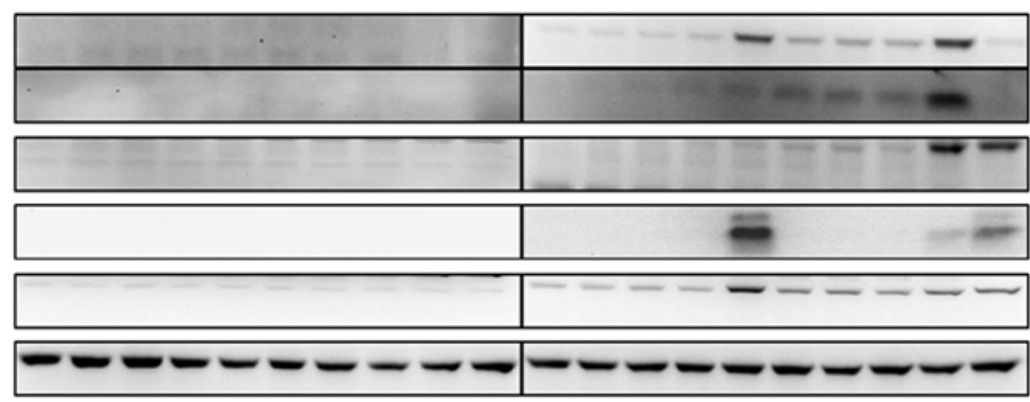

B

\section{Dimethylarsenic acid}

C

\section{Dimethylarsenic acid}
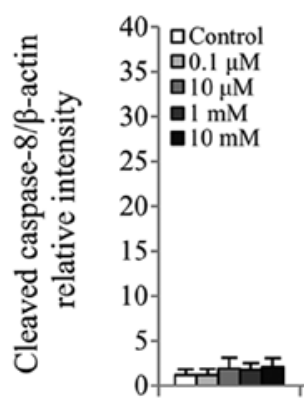

3

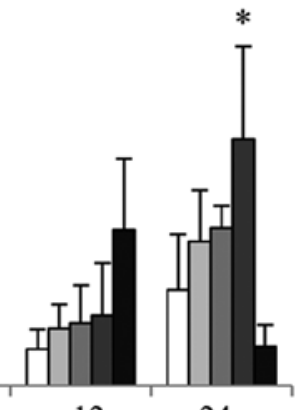

12

24

Elapsed time (h)

D

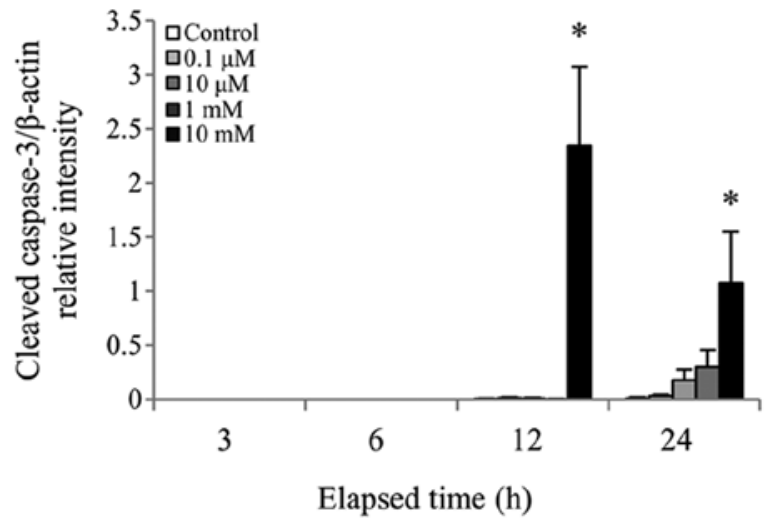

Dimethylarsenic acid
$\mathbf{E}$

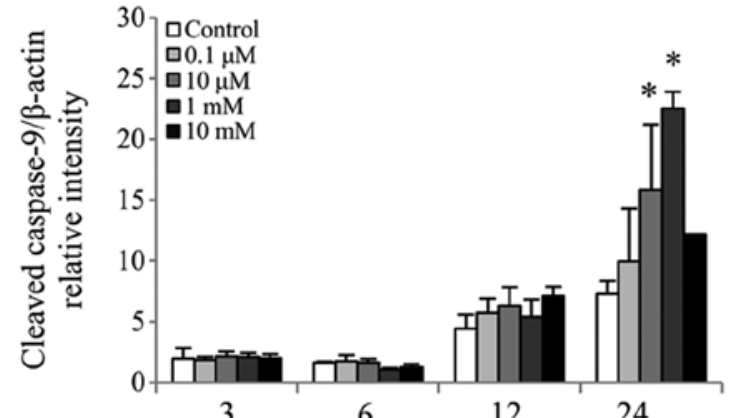

6

12

24

Elapsed time (h)

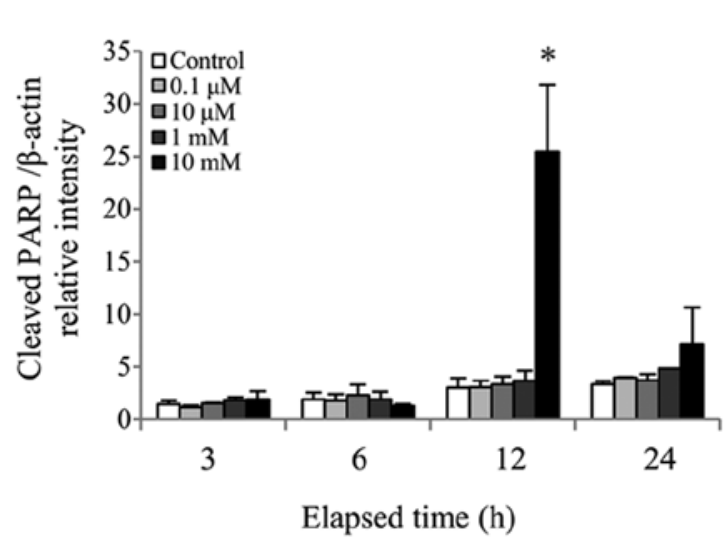

Figure 5. Effect of dimethylarsenic acid on cleaved caspase-8, -9 and -3 and PARP protein expression in MA-10 cells. MA-10 cells were treated without or with dimethylarsenic acid $(0.1 \mu \mathrm{M}-10 \mathrm{mM})$ for $3,6,12$, and $24 \mathrm{~h}$. Cleaved caspase- $8,-9$ and -3 , and PARP protein expression was detected by western blotting. (A) Data are representative of one experiment that was further repeated three times. The integrated optical densities of cleaved (B) caspase-8, (C) -9 and (D) -3 , and (E) PARP protein expression was analyzed after normalization to $\beta$-actin. Data in (B-E) represent the means \pm standard error of the mean of three separate experiments. ${ }^{*} \mathrm{P}<0.05$. PARP, poly(ADP-ribose) polymerase.

myeloma (42) and ovarian cancer cells (43). Furthermore, arsenic trioxide induces apoptosis of human keratinocytes via the Fas/FasL pathway (21). In MA-10 cells, caspase- 8 and -9 activation was observed following treatment with DMA and sodium arsenite for 12 or $24 \mathrm{~h}$, respectively. In addition, caspase inhibition reversed arsenicinduced MA-10 cell apoptosis. However, caspase-3 cleavage was re-activated when the cleavage of caspase- 8 and -9 was inhibited following treatment with 0.1-10 $\mu \mathrm{M}$ Z-VAD-fmk. This observation, at present, is difficult to explain, and therefore merits being investigated in further studies. Treatment with $100 \mu \mathrm{M}$ Z-VAD-fmk decreased cleavedcaspase- $8,-9$ and -3 protein levels. These results therefore demonstrated that both arsenic compounds activated the intrinsic and extrinsic apoptotic pathways and induced MA-10 cell apoptosis, which had been reported in previous studies $(21,42,43)$.

Taken together, the results from the present study indicated that arsenic compounds induce apoptosis in vitro. These observations, particularly the higher potency of sodium arsenite, suggest that arsenic compounds may have potential anti-tumorigenic therapeutic application in order to improve the outcome of patients with testicular cancer. 
A
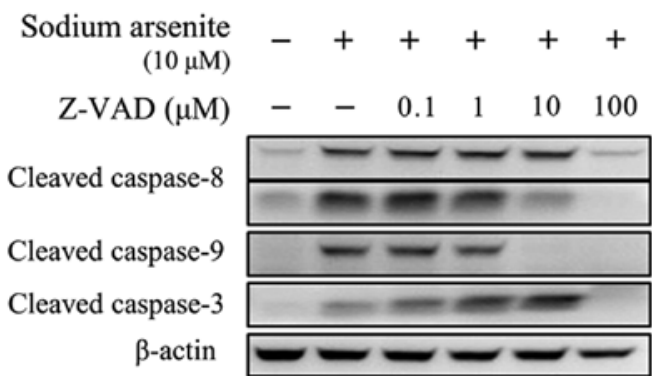

B

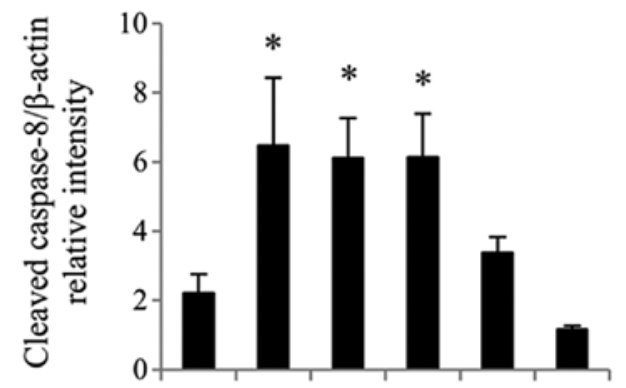

$\underset{(10 \mu \mathrm{M})}{\operatorname{Sodium}} \underset{\mathrm{arsenite}}{-}++\quad+\quad+$

$\mathrm{Z}-\mathrm{VAD}(\mu \mathrm{M}) \quad-\quad-\quad \begin{array}{lllll}0.1 & 1 & 10 & 100\end{array}$

C

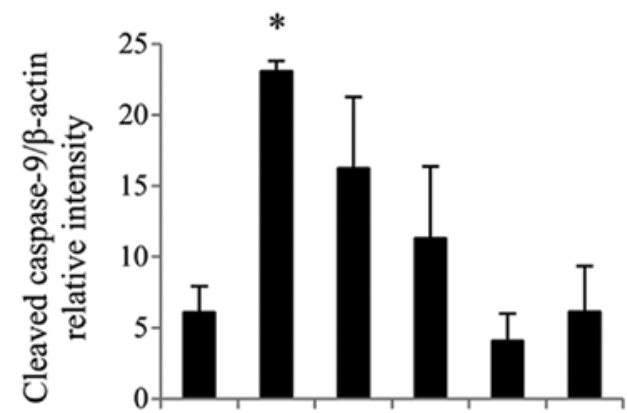

Sodium arsenite -+++++ $\mathrm{Z}-\mathrm{VAD}(\mu \mathrm{M}) \quad-\quad-\quad 0.1 \quad 1 \quad 10 \quad 100$

D

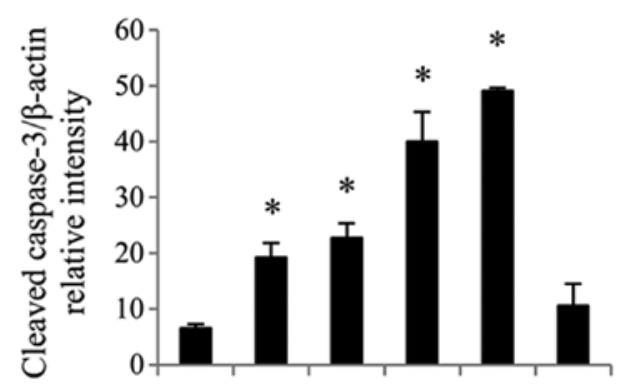

Sodium arsenite -++++

Z-VAD $(\mu \mathrm{M}) \quad-\quad-\quad 0.1 \quad 1 \quad 10 \quad 100$

Figure 6. Caspase inhibitor Z-VAD-fmk reverses sodium arsenic-induced caspase cleavage in MA-10 cells. MA-10 cells were pretreated with Z-VAD-fmk for $2 \mathrm{~h}$ and co-treated with or without $10 \mu \mathrm{M}$ sodium arsenite for $24 \mathrm{~h}$. Cleaved caspase- $8,-9$ and -3 protein expression was detected by western blotting. (A) Data are representative of one experiment that was further repeated three times. The integrated optical densities of cleaved (B) caspase-8, (C) -9 and (D) -3 protein expression were analyzed after normalization to Bactin. Data in (B), (C) and (D) represent the mean \pm standard error of the mean of three separate experiments. ${ }^{*} \mathrm{P}<0.05$.
A

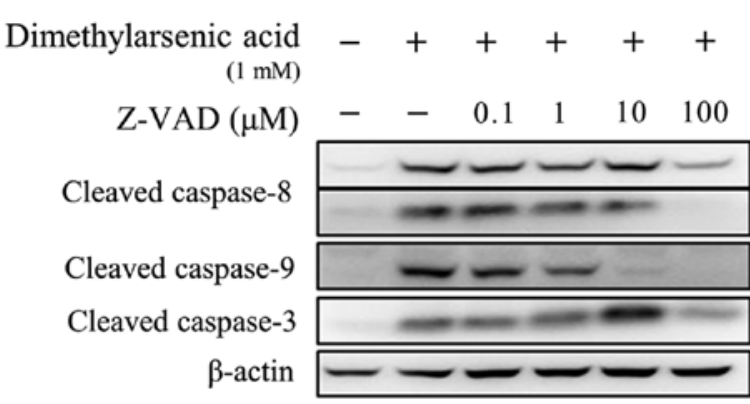

B

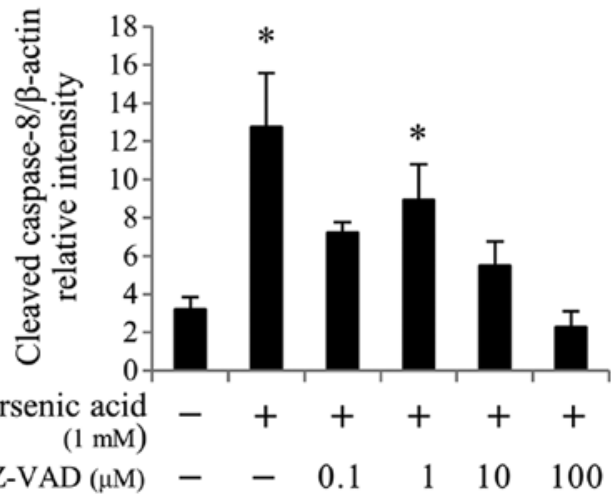

C

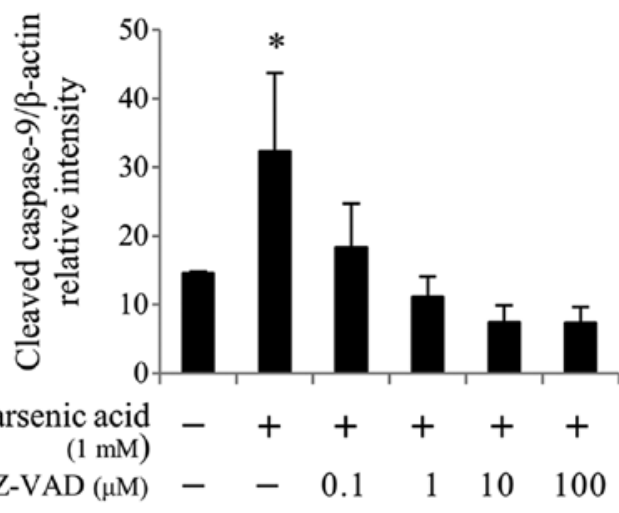

D

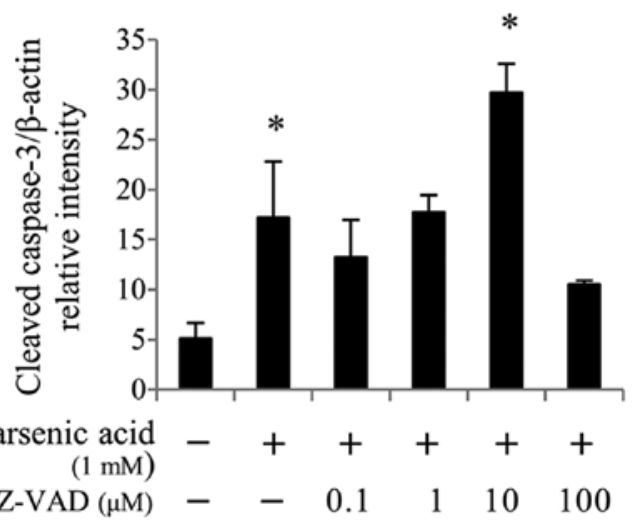

Figure 7. Caspase inhibitor Z-VAD-fmk reverses dimethylarsenic acid-induced caspase cascade in MA-10 cells. MA-10 cells were pretreated with Z-VAD-fmk for $2 \mathrm{~h}$ and co-treated with or without $1 \mathrm{mM}$ dimethylarsenic acid for $24 \mathrm{~h}$. Cleaved caspase-8, -9 and -3 protein expression was detected by western blotting. (A) Data are representative of one experiment that was further repeated three times. The integrated optical densities of cleaved (B) caspase-8, (C) -9 and (D) -3 protein expression were analyzed after normalization to $\beta$-actin. Data in (B), (C) and (D) represent the mean \pm standard error of the mean of three separate experiments. ${ }^{*} \mathrm{P}<0.05$. 


\section{Acknowledgements}

Not applicable.

\section{Funding}

The present study was supported by the Ministry of Science and Technology (grant no. MOST 105-2320-B-006-001).

\section{Availability of data and materials}

The datasets used and/or analyzed during the present study are available from the corresponding author on reasonable request.

\section{Authors' contributions}

YFM and YHC contributed to conduct the experiments, figure generations and statistical analysis. MMC designed the experiment and wrote the manuscript. YCC and BMH contributed to experimental design, data interpretation, writing of the manuscript, and ensuring the accuracy and the integrity of the work. All authors read and approved the final version of the manuscript.

\section{Ethics approval and consent to participate}

Not applicable.

\section{Patients consent for publication}

Not applicable.

\section{Competing interests}

The authors declare that they have no competing interest.

\section{References}

1. Styblo M, Del Razo LM, Vega L, Germolec DR, LeCluyse EL, Hamilton GA, Reed W, Wang C, Cullen WR and Thomas DJ: Comparative toxicity of trivalent and pentavalent inorganic and methylated arsenicals in rat and human cells. Arch Toxicol 74: 289-299, 2000.

2. Rosen BP: Biochemistry of arsenic detoxification. FEBS Lett 529: 86-92, 2002.

3. Chen GQ, Shi XG, Tang W, Xiong SM, Zhu J, Cai X, Han ZG, $\mathrm{Ni} \mathrm{JH}$, Shi GY, Jia PM, et al: Use of arsenic trioxide $\left(\mathrm{As}_{2} \mathrm{O}_{3}\right)$ in the treatment of acute promyelocytic leukemia (APL): I. As2O3 exerts dose-dependent dual effects on APL cells. Blood 89: 3345-3353, 1997.

4. Singh ZN, Duong VH, Koka R, Zou Y, Sawhney S, Tang L, Baer MR, Ambulos N, El Chaer F and Emadi A: High-risk acute promyelocytic leukemia with unusual T/Myeloid immunophenotype successfully treated with ATRA and arsenic trioxide-based regimen. J Hematop 11: 67-74, 2018.

5. Uslu R, Sanli UA, Sezgin C, Karabulut B, Terzioglu E, Omay SB and Goker E: Arsenic trioxide-mediated cytotoxicity and apoptosis in prostate and ovarian carcinoma cell lines. Clin Cancer Res 6: 4957-4964, 2000.

6. Kim YJ, Chung JY, Lee SG, Kim JY, Park JE, Kim WR, Joo BS, Han SH, Yoo KS, Yoo YH and Kim JM: Arsenic trioxide-induced apoptosis in TM4 Sertoli cells: The potential involvement of p21 expression and $\mathrm{p} 53$ phosphorylation. Toxicology 285: 142-151, 2011.

7. Tang H, Jin Y, Jin S, Tan Z, Peng Z and Kuang Y: Arsenite inhibits the function of CD133+ CD13+ liver cancer stem cells by reducing PML and Oct4 protein expression. Tumour Biol 37: 14103-14115, 2016.
8. Dilda PJ and Hogg PJ: Arsenical-based cancer drugs. Cancer Treat Rev 33: 542-564, 2007.

9. Don AS, Kisker O, Dilda P, Donoghue N, Zhao X, Decollogne S, Creighton B, Flynn E, Folkman J and Hogg PJ: A peptide trivalent arsenical inhibits tumor angiogenesis by perturbing mitochondrial function in angiogenic endothelial cells. Cancer Cell 3: 497-509, 2003.

10. Duzkale H, Jilani I, Orsolic N, Zingaro RA, Golemovic M, Giles FJ, Kantarjian H, Albitar M, Freireich EJ and Verstovsek S: In vitro activity of dimethylarsinic acid against human leukemia and multiple myeloma cell lines. Cancer Chemother Pharmacol 51: 427-432, 2003.

11. Velloso FJ, Bianco AF, Farias JO, Torres NE, Ferruzo PY, Anschau V, Jesus-Ferreira HC, Chang TH, Sogayar MC, Zerbini LF and Correa RG: The crossroads of breast cancer progression: Insights into the modulation of major signaling pathways. Onco Targets Ther 10: 5491-5524, 2017.

12. Derakhshan A, Chen Z and Van Waes C: Therapeutic small molecules target inhibitor of apoptosis proteins in cancers with deregulation of extrinsic and intrinsic cell death pathways. Clin Cancer Res 23: 1379-1387, 2017.

13. Lam M, Lawrence DA, Ashkenazi A and Walter P: Confirming a critical role for death receptor 5 and caspase- 8 in apoptosis induction by endoplasmic reticulum stress. Cell Death Differ 25: 1530-1531, 2018

14. Zimmermann KC, Bonzon $\mathrm{C}$ and Green DR: The machinery of programmed cell death. Pharmacol Ther 92: 57-70, 2001.

15. Taylor RC, Cullen SP and Martin SJ: Apoptosis: Controlled demolition at the cellular level. Nat Rev 9: 231-241, 2008.

16. Cory S and Adams JM: The Bcl2 family: Regulators of the cellular life-or-death switch. Nat Rev Cancer 2: 647-656, 2002.

17. Antonsson B, Montessuit S, Sanchez B and Martinou JC: Bax is present as a high molecular weight oligomer/complex in the mitochondrial membrane of apoptotic cells. J Biol Chem 276: 11615-11623, 2001.

18. Huang DC and Strasser A: BH3-Only proteins-essential initiators of apoptotic cell death. Cell 103: 839-842, 2000.

19. Andreu-Fernández V, García-Murria MJ, Bañó-Polo M, Martin J, Monticelli L, Orzáez M and Mingarro I: The C-terminal domains of apoptotic $\mathrm{BH} 3$-only proteins mediate their insertion into distinct biological membranes. J Biol Chem 291: 25207-25216, 2016.

20. Morales AA, Gutman D, Lee KP and Boise LH: BH3-only proteins Noxa, Bmf, and Bim are necessary for arsenic trioxide-induced cell death in myeloma. Blood 111: 5152-5262, 2009.

21. Liao WT, Chang KL, Yu CL, Chen GS, Chang LW and Yu HS: Arsenic induces human keratinocyte apoptosis by the FAS/FAS ligand pathway, which correlates with alterations in NF-kappaB and AP-1 activity. J Invest Dermatol 122: 125-129, 2004.

22. Huyghe E, Matsuda T and Thonneau P: Increasing incidence of testicular cancer worldwide: A review. J Urol 170: 5-11, 2003

23. Bertram KA, Bratloff B, Hodges GF and Davidson H: Treatment of malignant Leydig cell tumor. Cancer 68: 2324-2329, 1991.

24. Chang MM, Lai MS, Hong SY, Pan BS, Huang H, Yang SH, Wu CC, Sun HS, Chuang JI, Wang CY and Huang BM: FGF9/FGFR2 increase cell proliferation by activating ERK1/2, $\mathrm{Rb} / \mathrm{E} 2 \mathrm{~F} 1$, and cell cycle pathways in mouse Leydig tumor cells. Cancer Sci 109: 3503-3518, 2018.

25. Segaloff DL, Ascoli M and Puett D: Characterization of the desensitized state of Leydig tumor cells. Biochim Biophys Acta 675: 351-358, 1981

26. Wu WC, Hsiao JR, Lian YY, Lin CY and Huang BM: The apoptotic effect of cordycepin on human OEC-M1 oral cancer cell line. Cancer Chemother Pharmacol 60: 103-111, 2007.

27. Green LM, Reade JL and Ware CF: Rapid colorimetric assay for cell viability: Application to the quantitation of cytotoxic and growth inhibitory lymphokines. J Immunol Methods 70: 257-268, 1984.

28. Riccardi C and Nicoletti I: Analysis of apoptosis by propidium iodide staining and flow cytometry. Nat Protoc 1: 1458-1461, 2006.

29. Kang FC, Wang SC, Chang MM, Pan BS, Wong KL, Cheng KS, So EC and Huang BM: Midazolam activates caspase, MAPKs and ER stress pathways, and inhibits cell cycle and Akt pathway, to induce apoptosis in TM3 mouse Leydig progenitor cells. Onco Targets Ther 11: 1475-1490, 2018.

30. So EC, Chen YC, Wang SC, Wu CC, Huang MC, Lai MS, Pan BS, Kang FC and Huang BM: Midazolam regulated caspase pathway, endoplasmic reticulum stress, autophagy, and cell cycle to induce apoptosis in MA-10 mouse Leydig tumor cells. Onco Targets Ther 9: 2519-2533, 2016. 
31. Lowry OH, Rosebrough NJ, Farr AL and Randall RJ: Protein measurement with the Folin phenol reagent. J Biol Chem 193: 265-275, 1951.

32. Chen YH, Leu SF, Jen CY and Huang BM: Effects of sesamol on apoptosis and steroidogenesis in MA-10 mouse Leydig tumor cells. J Agric Food Chem 59: 9885-9891, 2011.

33. Pao HY, Pan BS, Leu SF and Huang BM: Cordycepin stimulated steroidogenesis in MA-10 mouse Leydig tumor cells through the protein kinase C Pathway. J Agric Food Chem 60: 4905-4913, 2012.

34. Chen YC, Chen YH, Pan BS, Chang MM and Huang BM: Functional study of Cordyceps sinensis and cordycepin in male reproduction: A review. J Food Drug Anal 25: 197-205, 2017.

35. Mullen P: PARP cleavage as a means of assessing apoptosis. Methods Mol Med 88: 171-181, 2004.

36. Hassani S, Khaleghian A, Ahmadian S, Alizadeh S, Alimoghaddam K, Ghavamzadeh A and Ghaffari SH: Redistribution of cell cycle by arsenic trioxide is associated with demethylation and expression changes of cell cycle related genes in acute promyelocytic leukemia cell line (NB4). Ann Hematol 97: 83-93, 2018.

37. Snow ET: Metal carcinogenesis: Mechanistic implications. Pharmacol Ther 53: 31-65, 1992.

38. Styblo M, Del Razo LM, LeCluyse EL, Hamilton GA, Wang C, Cullen WR and Thomas DJ: Metabolism of arsenic in primary cultures of human and rat hepatocytes. Chem Res Toxicol 12 : $560-565,1999$.
39. Hong SK, Wu PK and Park JI: A cellular threshold for active ERK1/2 levels determines Raf/MEK/ERK-mediated growth arrest versus death responses. Cell Signal 42: 11-20, 2018.

40. Diepart C, Karroum O, Magat J, Feron O, Verrax J, Calderon PB, Gregoire V, Leveque P, Stockis J, Dauguet N, et al: Arsenic trioxide treatment decreases the oxygen consumption rate of tumor cells and radiosensitizes solid tumors. Cancer Res 72: 482-490, 2012.

41. McCabe MJ, Singh KP, Reddy SA, Chelladurai B, Pounds JG, Reiners JJ and States JC: Sensitivity of myelomonocytic leukemia cells to arsenite-induced cell cycle disruption, apoptosis, and enhanced differentiation is dependent on the inter-relationship between arsenic concentration, duration of treatment, and cell cycle phase. J Pharmacol Exp Ther 295: 724-733, 2000.

42. Hayashi $T$, Hideshima $T$, Akiyama M, Richardson $P$, Schlossman RL, Chauhan D, Munshi NC, Waxman S and Anderson KC: Arsenic trioxide inhibits growth of human multiple myeloma cells in the bone marrow microenvironment. Mol Cancer Ther 1: 851-860, 2002.

43. Yuan Z, Wang F, Zhao Z, Zhao X, Qiu J, Nie C and Wei Y: BIM-mediated AKT phosphorylation is a key modulator of arsenic trioxide-induced apoptosis in cisplatin-sensitive and -resistant ovarian cancer cells. PLoS One 6: e20586, 2011. 